BIODIK: Jurnal IImiah Pendidikan Biologi
ISSN 2580-0922 (online), ISSN 2460-2612 (print)
Volume 6, Nomor 02, Tahun 2020, Hal. 159-167
Available online at:
https://online-journal.unja.ac.id/biodik

Research Article

open Access

\title{
Aplikasi Edible Coating Pati Kulit Singkong (Manihot utilisima Pohl.) pada Tomat (Solanum Lycopersicum L.) serta Uji Kadar Total Fenol dan Kadar Vitamin C sebagai Sumber Belajar
}

\author{
(Edible Coating Application of Cassava Peel Starch (Manihot utilisima Pohl.) On Tomato \\ (Solanum Lycopersicum L.) and Total Phenolic Content and Vitamin C Test for Learning \\ Resources)
}

Iqna Yudiyanti*, Sabirin Matsjeh

Program Studi Pendidikan Biologi, Universitas Ahmad Dahlan, Yogyakarta

Jl. Ringroad Selatan, Tamanan, Banguntapan, Bantul, Yogyakarta-Indoensia 55166

${ }^{*}$ Corresponding Author: Iqnayudiyanti32@gmail.com

\begin{tabular}{|c|c|}
\hline Informasi Artikel & ABSTRACT \\
\hline $\begin{array}{l}\text { Submit: } 14-05-2020 \\
\text { Diterima: } 03-06-2020 \\
\text { Dipublikasikan: } 11-06-2020\end{array}$ & $\begin{array}{l}\text { Cassava peel was determined to be underutilized by the community } \\
\text { that it turned out to be wasted. Cassava peel contains starch which } \\
\text { has a potential as an edible coating. During post-harvest, Tomatoes } \\
\text { are easily to loose Phenol and Vitamin C. Therefore, there should be } \\
\text { solutions to keep Phenol and Vitamin C level on Tomatoes through } \\
\text { edible coating application of Cassava Peel Starch. This study aims to } \\
\text { find out the effect of edible coating application of cassava peel starch } \\
\text { with concentrations of } 1 \%, 2 \% \text { and } 4 \% \text { on the Total Phenolic Content } \\
\text { and Vitamin C in tomatoes on day } 3,6 \text { and 12; as well as to find out } \\
\text { the present research's potential as learning resources for grade VIII } \\
\text { of Junior High School in learning Additive Substance. Total Phenolic } \\
\text { Content was tested using spectrophotometric, while Vitamin C } \\
\text { content was tested using lodine titration. The results show that the } \\
\text { highest Total Phenolic Content and Vitamin C occured on day } 12 \text { in } \\
\text { the } 4 \% \text { of edible coating treatment, respectively: 0.0525\% and } \\
33.2210 m g \text { /100g. According to the results, a conclusion could be } \\
\text { made that edible coating of cassava peel starch is able to maintain } \\
\text { Total Phenolic Content and Vitamin C on Tomatoes, compared to the } \\
\text { control. The results of the study could be used as learning resources } \\
\text { for grade VIII of Junior High School in learning Additive Substance. } \\
\text { Keywords: Cassava peel starch, Tomatoes, Total Phenolic Content, } \\
\text { Vitamin C, Learning resources }\end{array}$ \\
\hline Penerbit & ABSTRAK \\
\hline $\begin{array}{l}\text { Program Studi Pendidikan } \\
\text { Biologi, Fakultas Keguruan dan } \\
\text { IImu Pendidikan, Universitas } \\
\text { Jambi }\end{array}$ & $\begin{array}{l}\text { Kulit singkong kurang dimanfaatkan oleh masyarakat sehingga } \\
\text { menjadi limbah. Kulit singkong mengandung pati yang berpotensi } \\
\text { sebagai edible coating. Tomat mudah mengalami kerusakan pasca } \\
\text { panen sehingga kadar total fenol dan vitamin } \mathrm{C} \text { menurun, maka perlu } \\
\text { adanya alternatif untuk mempertahankan kadar total fenol dan vitamin } \\
\mathrm{C} \text { tomat dengan cara aplikasi edible coating pati kulit singkong. } \\
\text { Tujuan dari penelitian ini adalah untuk mengetahui pengaruh adanya } \\
\text { aplikasi edible coating pati kulit singkong konsentrasi } 1 \%, 2 \% \text { dan } 4 \% \\
\text { terhadap kadar total fenol dan kadar vitamin } \mathrm{C} \text { tomat hari ke } 3,6 \text { dan } \\
12 \text { serta mengetahui potensi hasil penelitian sebagai sumber belajar } \\
\text { IPA SMP kelas VIII materi zat aditif. Kadar total fenol diuji } \\
\text { menggunakan metode spektrofotometri dan kadar vitamin C } \\
\text { menggunakan metode titrasi iodium. Hasil penelitian menunjukan } \\
\text { kadar total fenol dan kadar vitamin C tertinggi terjadi pada hari ke } 12\end{array}$ \\
\hline
\end{tabular}



mempertahankan kadar total fenol dan vitamin $\mathrm{C}$ tomat dibandingkan kontrol. Hasil penelitian dapat digunakan sebagai sumber belajar IPA SMP kelas VIII materi zat aditif.

Katakunci: Pati kulit singkong, tomat, Total fenol, Vitamin C, Sumber belajar

This BIODIK : Jurnal IImiah Pendidikan Biologi is licensed under a CC BY-NC-SA (Creative Commons Attribution-ShareAlike 4.0 International License)

\section{PENDAHULUAN}

Sumber belajar merupakan sesuatu yang dapat dimanfaatkan untuk memberi kemudahan dalam belajar. Sumber belajar merupakan pesan, orang, bahan, alat, teknik, dan latar yang dimanfaatkan peserta didik sebagai sumber untuk kegiatan belajar dan dapat meningkatkan kualitas belajarnya untuk mencapai tujuan pembelajaran (Jonassen, 2015; Harlis, H., \& Budiarti, R. S, 2017). Sumber belajar dapat berupa manusia, lingkungan, aktifitas, bahan serta alat (Warso, 2013). Sumber belajar dapat meningkatkan keterampilan peserta didik (Sadikin, A., \& Hakim, N, 2019). Berdasarkan hasil wawancara salah satu guru IPA SMP, diketahui bahwa pada pembelajaran IPA khususnya materi zat aditif guru menggunakan sumber belajar buku paket IPA dan bahan ajar Lembar Kegiatan Peserta Didik (LKPD) namun belum menjelaskan secara mendalam mengenai materi zat aditif. Oleh karena itu, penggunaan sumber belajar perlu dikembangkan guna menambah pengetahuan peserta didik misalnya sumber belajar dari hasil penelitian. Menurut Suhardi (2012) hasil penelitian diangkat sebagai sumber belajar, jika sesuai dengan materi yang berlaku. Hasil penelitian berupa fakta yang diperoleh selama penelitian dan dikaitkan dengan konsep dan prinsip. Hasil Penelitian berupa gambar yang dapat meningkatkan pemahaman dan pengetahuan peserta didik (Pratiwi, N., Gardjito, G., \& Hamidah, A, 2017; Arifah, D., Sntoso, H., \& Noor, R, 2017).

Zat aditif merupakan bahan yang ditambahkan untuk meningkatkan mutu, cita rasa, memantapkan bentuk, serta memperpanjang masa simpan makanan. Penggunaan zat aditif alami misalnya pengapliasian edible coating dari bahan alami. Edible coating merupakan lapisan tipis yang dapat melindungi buah dan sayur karena berfungsi sebagai barrier yang menjaga kelembaban, bersifat permeable, dan mengontrol migrasi komponen-komponen larut air yang dapat merubah komposisi nutrisi (Usni, Karo-karo, \& Yusraini, 2016).

Singkong memiliki kulit yang relatif tebal dan kurang dimanfaatkan oleh masyarakat sehingga menjadi limbah. Menurut Richana (2012) kulit singkong bagian dalam mengandung protein, serat kasar, lemak kasar, kalsium dan fosfor serta memiliki kandungan pati yang cukup tinggi dapat dimanfaatkan sebagai bahan dasar edible coating. Buah tomat mengandung total fenol dan vitamin C sebagai antioksidan yang baik bagi tubuh, namun tomat mudah kerusakan pasca panen sehingga kadar total fenol dan vitamin C menurun. Menurut Eveline dkk. (2014) 
fenolik akan menurun pada hari ke-6 penyimpanan yang disebabkan laju respirasi tomat sebagai pemicu pembentukan fenolik. Selain itu, kadar vitamin $C$ tomat akan mengalami penurunan seiring pematangan buah. Oleh karena itu, perlu adanya alternatif untuk mempertahankan kadar total fenol dan kadar vitamin $\mathrm{C}$ tomat dengan cara aplikasi edible coating pati kulit singkong pada tomat. Tujuan dari penelitia ini adalah untuk mengetahui pengaruh adanya aplikasi edible coating pati kulit singkong (Manihot utilisima Pohl.) terhadap kadar total fenol dan kadar vitamin C tomat (Solanum lycopersicum L.). Hasil dari penelitian ini dianalisis potensinya sebagai sumber belajar IPA SMP kelas VIII materi zat aditif.

\section{METODE PENELITIAN}

\section{BAHAN}

Bahan dalam penelitian ini adalah Tomat (Solanum lycopersicum L.) dan kulit singkong (Manihot utilisima Pohl.) yang diolah menjadi pati.

\section{PROSEDUR PENELITIAN}

\section{Pemisahan pati kulit singkong}

Pemisahan pati kulit singkong dimulai dengan memisahkan kulit singkong bagian luar dan bagian dalam kemudian di bersihkan kulit bagian dalam. Pembuatan pati kulit singkong menggunakan metode Usni (2016) yang di modifikasi yaitu kulit singkong bagian dalam yang telah dicuci kemudian dipotong hingga ukuran panjangnya $\pm 1 \mathrm{~cm}$. Kemudian direndam dengan air selama 24 jam dan air diganti setiap 8 jam, setelah itu ditiriskan. Potongan kulit singkong ditambahkan air dengan perbandingan 1:3 dan dihaluskan dengan blender, untuk menghasilkan bubur kulit singkong. Kemudian bubur kulit singkong disaring dan diendapkan selama 24 jam. Air dibuang sehingga diperoleh pati kulit singkong. Pati dikeringkan dalam oven pada suhu $60 \stackrel{\circ}{\circ}$ selama 13 jam. Setelah kering pati dihaluskan dengan blender dan disaring.

\section{Pembuatan Larutan Pati 1\%, 2\% dan 4\%}

Pembuatan larutan pati $1 \%(\mathrm{~b} / \mathrm{v})$ dilakukan dengan melarutkan 1 gram dalam $100 \mathrm{~mL}$ aquades didalam erlenmeyer kemudian diaduk. Larutan pati $2 \%(\mathrm{~b} / \mathrm{v})$ dibuat dengan melarutkan 2 gram pati dalam $100 \mathrm{~mL}$ aquades. Larutan pati $4 \%$ dibuat dengan melarutkan 4 gram pati dalam $100 \mathrm{~mL}$ aquades kemudian diaduk. Larutan pati $1 \%, 2 \%$ dan $4 \%$ dibuat secara terpisah.

\section{Pembuatan Edible Coating dari Pati Kulit Singkong}

Pembuatan edible coating dari pati kulit singkong dengan konsentrasi 1\%, $2 \%$ dan $4 \%$ dibuat dalam gelas beker terpisah. Tahapan pembuatan edible coating pati kulit singkong diawali dengan melarutkan $\mathrm{CMC} 0,4 \%(\mathrm{~b} / \mathrm{v})$ diaduk pada suhu $70{ }^{\circ} \mathrm{C}$ sampai homogen selama 3 menit, kemudian ditambahkan pati kulit singkong (1\%, $2 \%$ dan $4 \%(\mathrm{~b} / \mathrm{v}))$ dan diaduk hingga homogen selama 3 menit, kemudian ditambahkan gliserol 5\% (v/v) dan diaduk selama 1 menit hingga homogen, setelah 
itu ditambahkan asam stearate $5 \%(\mathrm{~b} / \mathrm{v})$ dan diaduk selama 6 menit pada suhu $70 \stackrel{\circ}{ } \mathrm{C}$ (Dehya, 2015).

\section{Aplikasi Edible Coating Pati Kulit Singkong pada Tomat}

Tomat diaplikasikan dalam edible coating pati kulit singkong dengan mencelupkan tomat dalam formula edible coating selama 60 detik. Buah tomat ditiriskan selanjutnya sampel di simpan pada suhu ruang dan dilakukan uji kadar total fenol dan kadar vitamin C pada hari ke 3, 6 dan 12.

\section{Kadar Total Fenol}

Penetapan kadar total fenol menggunakan metode Spektrofotometri, mengacu pada prosedur J.B. Harborne (1987) Sampel tomat 5 gram dihaluskan dan dimasukan dalam labu ukur $100 \mathrm{~mL}$ kemudian ditambah aquades sampai tanda lalu disaring. Filtrate sampel sebanyak $1 \mathrm{~mL}$ dimasukan dalam tabung reaksi kemudian ditambahkan 0,5 $\mathrm{mL}$ follin denis (follin 1:1) dan ditambahkan $1 \mathrm{~mL}$ larutan $\mathrm{Na}_{2} \mathrm{CO}_{3}$ jenuh selanjutnya didiamkan selama 10 menit. Setelah itu ditambahkan aquades $7,5 \mathrm{~mL}$ kemudian divortex hingga homogen. Absorbasi larutan sampel tomat dibaca dengan menggunakan spektrofotometer pada panjang gelombang $730 \mathrm{~nm}$.

\section{Mengukur Kadar Vitamin C}

Penetapan kadar vitamin $C$ dengan titrasi iodium prosedur Jacobs. Sampel tomat 10 gram dihaluskan dan dimasukkan dalam labu ukur $100 \mathrm{~mL}$, ditambahkan aquades sampai batas, kemudian disaring. Sebanyak $10 \mathrm{ml}$ filtrate dimasukan dalam erlenmeyer $125 \mathrm{ml}$, kemudian ditambahkan $2 \mathrm{ml}$ larutan amilum (soluble starch) 1\%. Larutan kemudian dititrasi dengan 0,01 N standar lodium ( $1 \mathrm{~mL} 0,01 \mathrm{~N}$ lodium =0,88 $\mathrm{mg}$ asam askorbat) Titik akhir titrasi ditandai dengan adanya perubahan warna larutan menjadi \pm biru. Konsentrasi asam askorbat dihitung dengan rumus:

$$
\text { Vitamin C (mg/100g sampel })=\frac{(T \text { iter }(\mathrm{ml}) \times 0,88 \times \mathrm{fp})}{W \text { sampel }(\mathrm{g})} \times 100
$$

\section{Uji organoleptik}

Uji organoleptik tomat kontrol dan edible coating dilakukan dengan cara meminta panelis untuk mencicipi rasa tomat, dan mengamati warna, tekstur dan kenampakan kulit tomat pada hari ke 0, 3, 6 dan 12 dan mengisi kuisioner yang telah disediakan.

\section{Analisis hasil penelitian sebagai sumber belajar}

Analisis potensi hasil penelitian sebagai sumber belajar dilakukan dengan memperhatikan syarat hasil penelitian sebagai sumber belajar melalui beberapa prosedur menurut Suhardi (2012). Sumber belajar berupa poster yang mengkombinasikan gambar dengan unsur visual yang menarik perhatian serta dapat memberi pesan secara singkat (Anitah, 2009). Kriteria poster berdasarkan Hess dan Brook (1998) yaitu sederhana, menyajikan suatu ide, bewarna, slogannya ringkas, jelas, desain bervariasi serta tepat guna. 


\section{Analisis data}

Data diolah dengan analisis varian (One Way Anova) dan dilanjutkan uji LSD taraf $5 \%$. Uji organoleptik dan potensi hasil penelitian sebagai sumber belajar dianalisis secara kualitatif.

\section{HASIL DAN PEMBAHASAN}

\section{Kadar total fenol}

Hasil kadar total fenol pada tomat perlakuan edible coating 1\%, $2 \%, 4 \%$ dan kontrol ditunjukkan pada gambar 1 .

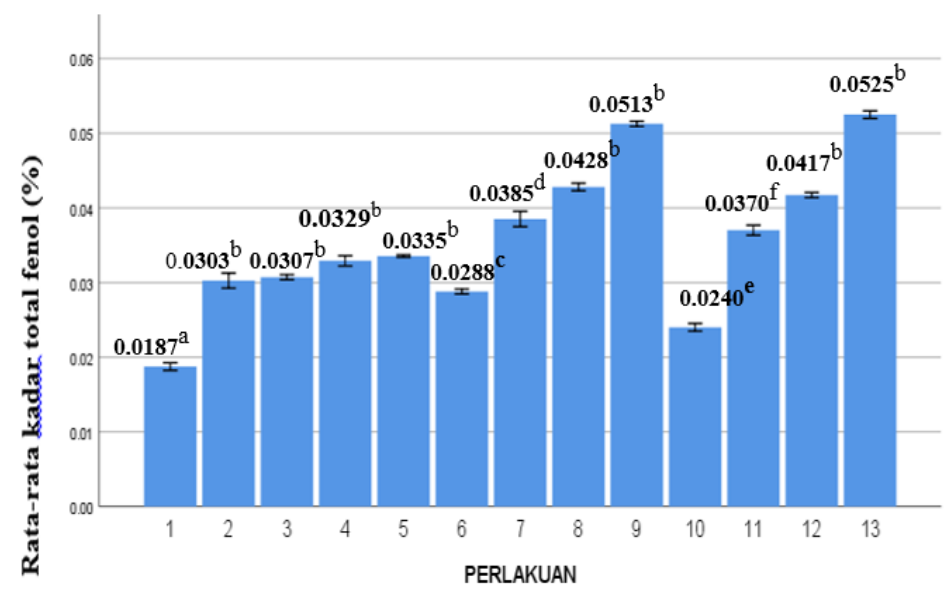

\section{Gambar 1. Perbandingan kadar total fenol tomat kontrol dan perlakuan edible coating $1 \%, 2 \%$ dan $4 \%$}

Keterangan;

1 : hari ke 0 (Kontrol)

6 : hari ke 6 (Kontrol)

10 : hari ke 12 (Kontrol)

2 : hari ke 3 (Kontrol)

7 : hari ke $6(1 \%)$

8 : hari ke $6(2 \%)$

11 : hari ke $12(1 \%)$

3 : hari ke $3(1 \%)$

4 : hari ke $3(2 \%)$

5 : hari ke $3(4 \%)$

9 : hari ke $6(4 \%)$

12 : hari ke $12(1 \%)$

13 : hari ke $12(2 \%)$

Tomat kontrol mengalami kenaikan pada hari ke 3 namun menurun pada hari ke 6 dan 12. Sesuai dengan penelitian Eveline dkk., (2014) fenolik akan menurun pada hari ke-6 penyimpanan yang disebabkan laju respirasi tomat sebagai pemicu pembentukan fenolik. Adanya aplikasi edible coating pada tomat maka laju respirasi tomat diperlambat. Perlakuan edible coating $1 \%$ dan $2 \%$ mengalami kenaikan pada hari ke 6 namun pada hari ke 12 mengalami penurunan sedangkan pada edible coating $4 \%$ tidak mengalami penurunan bahkan mengalami kenaikan, semakin tinggi konsentrasi pati kulit singkong maka semakin tebal pula lapisan yang dapat melindungi tomat, menyebabkan laju respirasi tomat edible coating $4 \%$ paling lambat dibandingkan perlakuan lain sehingga pembentukan fenolik tomat $4 \%$ terus terproses sampai penyimpanan 12 hari. Semakin tinggi konsentrasi larutan pati kulit singkong maka semakin tinggi pula kadar total fenol tomat pengukuran hari ke 3,6 dan 12 . Oleh karena itu, konsentrasi larutan pati kulit singkong $4 \%$ optimum dalam mempertahankan kadar total fenol tomat. 


\section{Kadar vitamin C}

Hasil kadar total fenol pada tomat perlakuan edible coating 1\%, $2 \%, 4 \%$ dan kontrol ditunjukkan pada gambar 2.

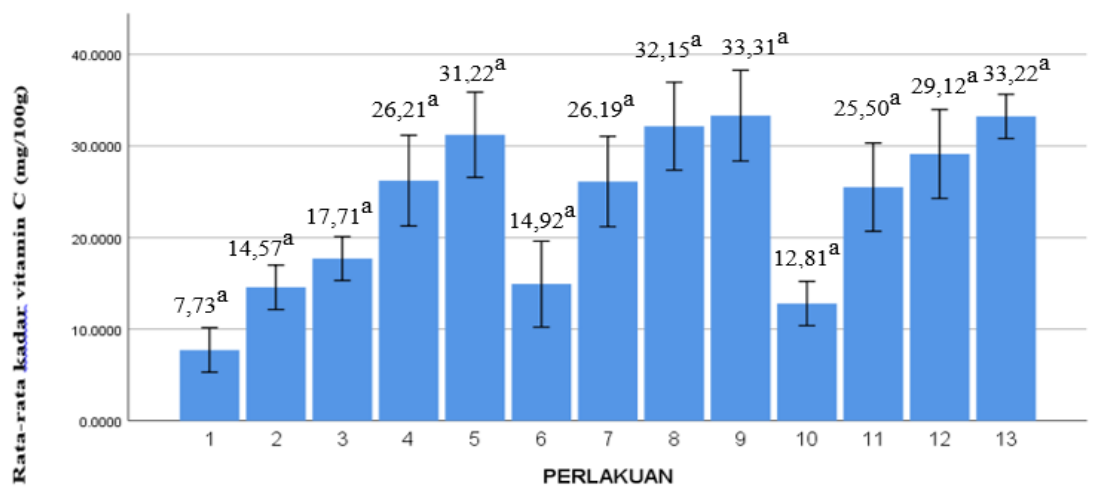

Gambar 2. Perbandingan kadar vitamin $\mathrm{C}$ tomat kontrol dengan edible coating pati kulit singkong $1 \%$, $2 \%$ dan $4 \%$

Keterangan:

1 : hari ke 0 (Kontrol)

2 : hari ke 3 (Kontrol)

6 : hari ke 6 (Kontrol)

7 : hari ke $6(1 \%)$

3 : hari ke $3(1 \%)$

4 : hari ke $3(2 \%)$

8 : hari ke $6(2 \%)$

9 : hari ke $6(4 \%)$

10 : hari ke 12 (Kontrol)

11 : hari ke $12(1 \%)$

12 : hari ke $12(1 \%)$

5 : hari ke $3(4 \%)$

13 : hari ke $12(2 \%)$

Tomat kontrol dan tomat semua perlakuan mengalami kenaikan kadar vitamin $C$ pada hari ke 3 dan 6 namun pada hari ke 12 mengalami penurunan. Sesuai dengan penelitian Eveline dkk., (2014) bahwa kadar vitamin C tomat akan mengalami penurunan seiring pematangan buah. Perubahan kadar vitamin C disebabkan terjadinya oksidasi L-ascorbid acid menjadi L-dhidroascorbid ataupun proses buah menjadi busuk (Miskiyah, 2011). Kadar vitamin C perlakuan 4\% paling sedikit penurunannya dibandingkan penurunan kadar vitamin $\mathrm{C}$ perlakuan $1 \%$ dan $2 \%$ serta tomat kontrol, maka pelakuan $4 \%$ optimum dalam mempertahankan kadar vitamin $\mathrm{C}$.

\section{Uji organoleptik}

Warna digunakan untuk menentukan baik tidaknya cara pengolahan makanan yang ditandai dengan adanya warna yang marata (Cahyadi, 2009). Menurut Elizarni (2014) warna yang segar dan mencolok umumnya mempengaruhi daya tarik dan lebih disukai konsumen. Hasil penelitian menunjukkan konsentrasi terbaik dalam tingkat kesukaan konsumen terhadap warna tomat yaitu konsentrasi $2 \%$. , sedangkan tingkat kesukaan konsumen terhadap rasa, tekstur dan kenampakan kulit tomat selama penyimpanan 12 hari pada konsentrasi 4\%. Rasa ditimbulkan oleh senyawa yang larut dalam air dan bereaksi dengan reseptor pada lidah (Elizarni, 2014). 


\section{Analisis hasil penelitian sebagai sumber belajar}

Hasil penelitian dapat diangkat sebagai sumber belajar karena memenuhi persyaratan hasil penelitian sebagai sumber belajar menurut prosedur Suhardi (2012). Menurut Syukur (2008) poster termasuk dalam sumber belajar. Dalam pembelajaran, poster dapat memvisualisasikan pesan dan informasi yang ingin disampaikan kepada peserta didik melalui gambar dari suatu objek (Maiyena, 2013). Sumber belajar dari hasil penelitian berupa poster disajikan dalam gambar 3 .

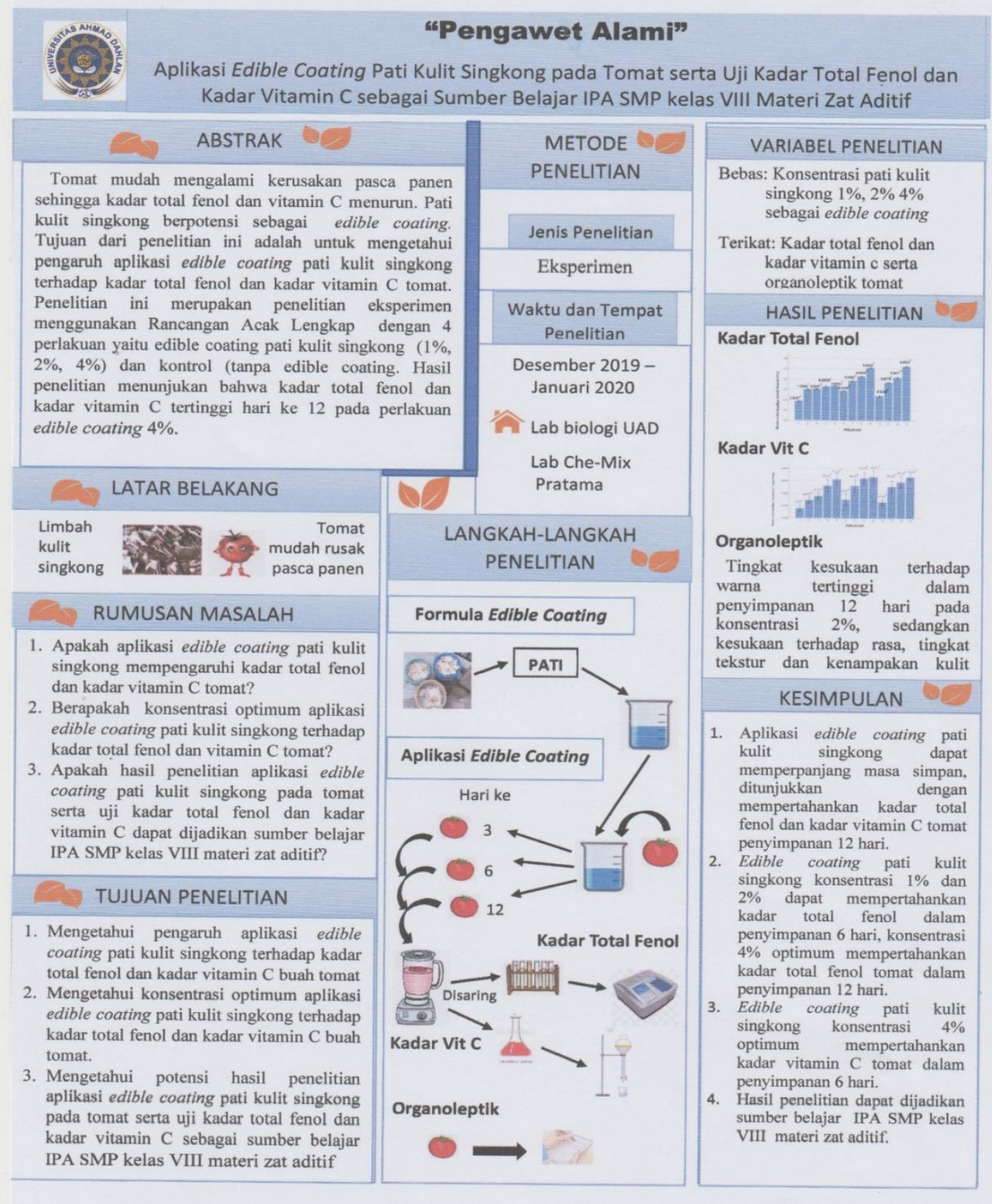

Gambar 3. Sumber belajar berupa poster dari hasil penelitian 
Aplikasi edible coating pati kulit singkong dapat memperpanjang masa simpan yang ditunjukkan dengan mempertahankan kadar total fenol dan kadar vitamin $\mathrm{C}$ pada buah tomat dalam waktu penyimpanan 12 hari. Edible coating pati kulit singkong konsentrasi $1 \%$ dan $2 \%$ dapat mempertahankan kadar total fenol penyimpanan 6 hari sedangkan konsentrasi $4 \%$ optimum mempertahankan kadar total fenol tomat penyimpanan 12 hari. Edible coating pati kulit singkong konsentrasi 4\% optimum mempertahankan kadar vitamin $C$ tomat penyimpanan 6 hari. Hasil penelitian aplikasi edible coating pati kulit singkong pada tomat serta uji kadar total fenol dan kadar vitamin $\mathrm{C}$ dapat dijadikan sumber belajar IPA SMP kelas VIII materi zat aditif.

\section{UCAPAN TERIMAKASIH}

Terimakasih kepada pihak Laboratorium Biologi Universitas Ahmad Dahlan dan Laboratorium Che-mix Pratama Yogyakarta, serta seluruh pihak yang telah membantu penelitian ini.

\section{DAFTAR PUSTAKA}

Anitah, S. (2009). Media Pembelajaran. Surakarta: Panitia Sertifikasi Guru Rayon 13 FKIP UNS.

Arifah, D., Sntoso, H., \& Noor, R. (2017). Indeks Keanekaragaman Echinodermata di Pantai Tanjung Setia Kabupaten Pesisir Barat Sebagai Sumber Belajar Biologi SMA Kelas X. BIOEDUKASI, 8(2), 117-124.

http://dx.doi.org/10.24127/bioedukasi.v8i2.1068

Cahyadi, W. (2009). Bahan Tambahan Pangan. Jakarta: bumi aksara.

Dehya, M. (2015). Aplikasi Edible Coating Berbasis Pati Singkong Untuk Memperpanjang Umur Simpan Buah Naga Terolah Minimal. Skripsi Institute Pertanian Bogor.

Eveline, T. M. S. dan S. (2014). STUDI AKTIVITAS ANTIOKSIDAN PADA TOMAT (Lycopersicon esculentum) KONVENSIONAL DAN ORGANIK SELAMA PENYIMPANAN. 22-28.

Firdausni elizarni, H. anwar dan R. sari. (2014). Stabilitas Ekstrak Kurkumin Kunyit dan Klorofil Daun Pandan Menggunakan Alfa Tocoferol dan Dekstrin. Litbang Industri, 4 (2), 97-103. http://dx.doi.org/10.24960/jli.v4i2.643.97-103.

Harborne, J. B. (1987). Metode Fitokimia: Penuntun Cara Modern Menganalisis Tumbuhan. Bandung: Penerbit ITB.

Harlis, H., \& Budiarti, R. S. (2017). Pengembangan bahan ajar praktikum dan instrumen penilaian berbasis keterampilan proses sains pada mata kuliah mikologi program studi pendidikan biologi universitas jambi. BIODIK, 3(2), 102112. https://doi.org/10.22437/bio.v3i2.5501.

Hess, G. dan Brook, E. (1998). The Class Poster Conference as a Teaching Tool. Journal of Natural Resources and Life Sciences Education, 27(1), 255-258.

Jonassen, D. (2015). PEMANFAATAN SUMBER BELAJAR DALAM PROSES PEMBELAJARAN Supriadi Fakultas Tarbiyah dan Keguruan UIN Ar-Raniry Banda Aceh. 3(2). 
Maiyena, S. (2013). Pengembangan Media Poster Berbasis Pendidikan Karakter untuk Materi Global Warming. Jurnal Materi Dan Pembelajaran Fisika, 3(1), 1826.

Miskiyah, Widaningrum \& C. winarti. (2011). Aplikasi Edible Coating Berbasis Pati Sagu dengan Penambahan Vitamin C pada Paprika: Preferensi Konsumen dan $\begin{array}{llll}\text { Mutu Mikrobiologi. Jurnal Hort, } & \text { 21(1), }\end{array}$ http://dx.doi.org/10.21082/jhort.v21n1.2011.p68-76.

Nur Richana. (2012). Ubi Kayu Dan Ubi Jalar. Bandung: Nuansa Cendikia.

Pratiwi, N., Gardjito, G., \& Hamidah, A. (2017). Pengembangan Majalah Biologi Sebagai Media Pembelajaran Pada Pokokbahasan Protista Kelas X Mia Di Sma N 7 Kota Jambi. Biodik, 3(1), 27-34. https://doi.org/10.22437/bio.v3i1.4880.

Sadikin, A., \& Hakim, N. (2019). Buku Ajar Berbantuan Model Pembelajaran Everyone is A Teacher Here: Upaya Meningkatkan Keterampilan Dasar Mengajar Calon Guru Biologi. Assimilation: Indonesian Journal of Biology Education, 2(2), 47-51. https://doi.org/10.17509/aiibe.v2i2.19249.

Suhardi. (2012). Pengembangan Sumber Belajar Biologi. Yogyakarta: FMIPA UNY. Syukur, F. (2008). Teknologi Pendidikan. Semarang: Rasail Media Group.

Usni, A., Karo-karo, T., \& Yusraini, E. (2016). The Effect of Edible Coating Based on Starch of Cassava Pell on The Quality and Shelf Life of Guava fruits at Room Temperature. 4(3), 293-303.

Warso, dan A. W. (2013). Proses Pembelajaran dan Penilaiannya di SD /MI/SMP/MTS/SMA/MA/SMK. Yogyakarta: Graha Cendekia. 